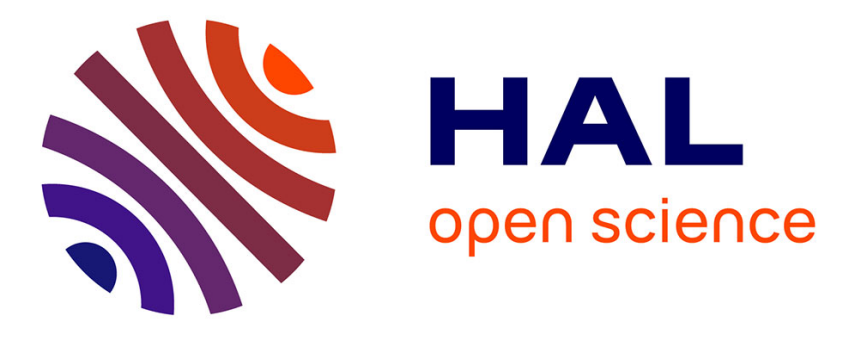

\title{
Biological functions and metabolism of oleoylethanolamide
}

\author{
Clémentine Thabuis, Delphine Tissot-Favre, Jean-Baptiste Bezelgues, \\ Jean-Charles Martin, Cristina Cruz-Hernandez, Fabiola Dionisi, Frédéric \\ Destaillats
}

\section{To cite this version:}

Clémentine Thabuis, Delphine Tissot-Favre, Jean-Baptiste Bezelgues, Jean-Charles Martin, Cristina Cruz-Hernandez, et al.. Biological functions and metabolism of oleoylethanolamide. Lipids, 2008, 43 (10), pp.887-894. 10.1007/s11745-008-3217-y · hal-02658710

\section{HAL Id: hal-02658710 https://hal.inrae.fr/hal-02658710}

Submitted on 30 May 2020

HAL is a multi-disciplinary open access archive for the deposit and dissemination of scientific research documents, whether they are published or not. The documents may come from teaching and research institutions in France or abroad, or from public or private research centers.
L'archive ouverte pluridisciplinaire HAL, est destinée au dépôt et à la diffusion de documents scientifiques de niveau recherche, publiés ou non, émanant des établissements d'enseignement et de recherche français ou étrangers, des laboratoires publics ou privés. 


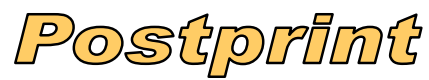

Version définitive du manuscrit publié dans / Final version of the manuscript published in : Lipids, 2008, Online First, DOI: 10.1007/s11745-008-3217-y

Clémentine Thabuis ${ }^{1}$, Delphine Tissot-Favre ${ }^{2}$, Jean-Baptiste Bezelgues ${ }^{2}$, Jean-Charles Martin ${ }^{1}$ Cristina Cruz-Hernandez ${ }^{2}$, Fabiola Dionisi ${ }^{2}$ and Frédéric Destaillats ${ }^{2, *}$

${ }^{1}$ INRA, UMR1260 «Nutriments Lipidiques et Prévention des Maladies Métaboliques», Marseille, F-13385 France ; INSERM, U476, Marseille, F-13385 France ; Univ Aix-Marseille 1, Univ Aix-Marseille 2, Faculté de Médecine, IPHM-IFR 125, Marseille, F-13385 France;

${ }^{2}$ Nestlé Research Center (Vers-chez-les-Blanc, P.O.Box 44, CH- 1000 LAUSANNE 26, (Switzerland)

Correspondence should be addressed:

17 Nestlé Research Center

18 Vers-chez-les-Blanc, P.O.Box 44

CH - 1000 LAUSANNE 26, Switzerland

E-mail: frederic.destaillats@rdls.nestle.com

$21 \quad$ Tel.:+41 217858937

22 Fax: +41 217858553 


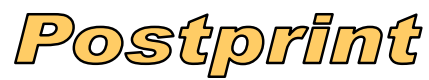

Version définitive du manuscrit publié dans / Final version of the manuscript published in : Lipids, 2008, Online First, DOI: 10.1007/s11745-008-3217-y

25

26

27

\section{ABSTRACT}

The present review is focussed on the metabolism and the emerging roles of oleoyethanolamide (OEA) with emphasis on its effects on food intake control and lipid metabolism. The biological mechanism of action including non-genomic effect mediated through peroxisome proliferator-activated receptor alpha (PPAR- $\alpha$ ) and transient receptor potential vanilloid type 1 (TRPV1) receptor are discussed. The research related to fatty acid ethanolamides has been focussed until recently on anandamide and its interaction with cannabinoid receptor subtype 1 (CB1). The roles of other $N$-acyl ethanolamine fatty acid derivatives have been neglected until it was demonstrate that OEA can modulate food intake control through interaction with PPAR- $\alpha$. Further investigations demonstrate that OEA modulate lipid and glucose metabolism and recent study confirmed that OEA is an antagonist of TRVP1. It has been demonstrated that OEA have beneficial effects on health by inducing food intake control, lipid $\beta$-oxidation, body weight loss and analgesic effects. The investigation of the mechanism of action revealed that OEA activates PPAR- $\alpha$ and stimulates the vagal nerve through the capsaicin receptors TRPV1. Pre-clinical studies showed that OEA remains active when administered orally.

Key words: $\mathrm{N}$-acyl fatty acid ethanolamine, food intake, oleoylethanolamide, energy metabolism, lipid metabolism. 


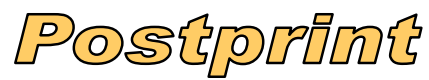

Version définitive du manuscrit publié dans / Final version of the manuscript published in : Lipids, 2008, Online First, DOI: 10.1007/s11745-008-3217-y

\section{INTRODUCTION}

Fatty acid ethanolamides (FAEA) belong to a family of lipids naturally found in both plant and animal tissues. These fatty acid derivatives appeared to have biological properties. Indeed, palmitoylethanolamide (derived from palmitic acid) have anti-nociceptive and antiinflammatory properties (1). Among this family, anandamide (derived from arachidonic acid) has been of great interest. In the last decade, it was discovered that anandamide is an endogenous ligand for cannabinoid receptor subtype 1 (CB1). Activating CB1, anandamide increases food intake. Another interesting fatty acid amide is oleoylethanolamide (OEA), formed from oleic acid and phosphatidylethanolamine. Biological functions of OEA, such as anorexigenic or body fat loss properties, have been extensively studied over the past decade. This molecule is naturally present at low concentrations in food products such as cocoa powder (up to $2 \mu \mathrm{g} / \mathrm{g}$ ), oatmeal or nuts $(2,3)$. Biologically, the OEA function is to regulate food intake via a synthesis/degradation balance, which occurs mainly in the enterocytes (brush border). The present review is focussed on these recently discovered biological functions of OEA, its metabolism and analysis.

\section{BIOLOGICAL FUNCTIONS OF OLEOYLETHANOLAMIDE (OEA)}

\subsection{Effect of oleoylethanolamide (OEA) on food intake control}

OEA is synthesized in the small intestine of various vertebrate species, where its level decreases during food deprivation and increase upon refeeding $(2,4,5)$. The increased level of plasmatic OEA after feeding could be due to the presence of OEA in food $(2,3)$, but OEA concentrations in food products are really low (under $2 \mu \mathrm{g} / \mathrm{g}$ of food), suggesting that one part of the increased level of OEA is linked to an activated endogenous synthesis. Indeed food intake may stimulate $\mathrm{N}$-acyltransferase activity and biosynthesized OEA can trigger satiety signals $(2,4,5)$. In brain, the anandamide concentration significantly increases upon severe food restriction. The level of this endocannabinoid is modulated in the brain structures 


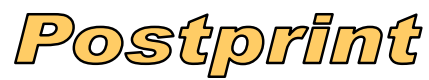

Version définitive du manuscrit publié dans / Final version of the manuscript published in : Lipids, 2008, Online First, DOI: 10.1007/s11745-008-3217-y

70 according to the feeding status, and depending on specific localization in the brain.

71 Anandamide levels do not change in the hypothalamus but increase in the limbic forebrain

72 (6). Anandamide and OEA were shown to be active through two distinct pathways. Thus,

anandamide activates cannabinoid receptors CB1 mainly in the mesolimbic system (6),

leading to an increase of food intake, whereas intestinal OEA induces a satiety signal leading

to a decrease of food intake. Similarly to anandamide, the natural levels of OEA change with respect to the nutritional status, leading to a precise control of food intake. This control is central to induce food intake and peripheral to induce satiety (5).

Pharmacological studies have been performed to better understand how a very simple fatty acid derivative can control food intake. A significant decrease of food intake was observed during 4 hours after intraperitoneal (ip) injection of OEA at $5 \mathrm{mg} / \mathrm{kg}$ of body weight and all over the 9 days of experiment in rats (7). The same treatment lowered also the body weight gain compared to control (7). Intracerebroventricular administration of OEA did not induced any effects underlying the peripheral action of OEA (4). Various OEA doses have been tested with ip administration from 5 to $20 \mathrm{mg} / \mathrm{kg}$ of body weight, always leading to a dose-dependant decrease of food intake. Compared to the control (animals injected with vehicles), the percentages of food intake decrease were 32,24 and $14 \%$ respectively for 20 , 10 and $5 \mathrm{mg}$ of OEA/kg bw on the 24 hours following the injection $(8,9)$. These measures were performed on $24 \mathrm{~h}$-experiment. The effects of OEA on food intake were reproducible until 14 days. Indeed, subchronic intraperitoneal administration of $5 \mathrm{mg}$ OEA/kg bw induced a global diminution of food consumption. Cumulative food intake was significantly decreased over 14 days of experiment but the daily food intake was not significantly lower compared to control among these experimental periods. Nevertheless, the subchronic OEA administration, with a daily injection of $5 \mathrm{mg} \mathrm{OEA} / \mathrm{kg}$ bw, induced a $3 \%$ significant decrease of body weight all over the experiment (10). 


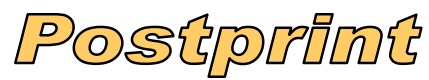

Version définitive du manuscrit publié dans / Final version of the manuscript published in : Lipids, 2008, Online First, DOI: 10.1007/s11745-008-3217-y

Further studies looking at the oral administration effect of OEA confirmed that OEA acts peripherally (11). When OEA was administrated by gavage at different concentrations, a significant decrease of food intake on $24 \mathrm{~h}$ was observed at $200 \mathrm{mg} / \mathrm{kg}$ of oral OEA (11). When OEA was administrated in pH-protective capsules (releasing OEA at $\mathrm{pH}$ 6), a similar effect was observed at a four fold lower level (50 mg/kg of body weight) (12). The effects of OEA capsules were significantly different from controls 5 hours after administration, what corresponds to the time for the capsules to go from the stomach to the small intestine. All together, these results suggest that OEA reduces food intake by acting at a local site within the small intestine (12). Several meal parameters have also been monitored and demonstrated that OEA induced a delay of the first meal, a decrease of the size of the first meal and an increase of the post meal intervals (12). It has been shown that ethanolamine and oleic acid, the degradation products of OEA, did not have any influence on food intake when administrated orally (11). A bioavailability study, using radiolabeled OEA administrated to rats by gavage (10 $\mathrm{mg} / \mathrm{kg}$ of body weight), has been performed to assess OEA degradation in gastrointestinal tract (11). This treatment increased the OEA level to about 11 times in intestinal tissue. However, only $0.48 \%$ of the given dose was found unchanged in the tissue. The ratio of intact OEA to hydrolyzed OEA decreased along the gastrointestinal tract, showing that OEA is progressively catabolized (11).

In parallel, studies have been performed to establish whether OEA has any influence on the synthesis of satiety signaling biomarkers such as Glucagon Like Peptide-1 (GLP-1), Cholecystokinin (CCK), and Peptide YY (PYY) that have satietogenic effects and ghrelin that stimulates appetite. These molecules act along the gastrointestinal tract and are secreted separately depending on the nutritional status. The satietogenic peptides GLP-1, CCK and PYY are released during the post-prandial period, whereas the ghrelin plasma level is increased under starvation. The alternative release of these different biomarkers contributes strongly to food consumption regulation. Ip injection of OEA was shown to reduce the ghrelin 


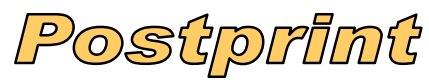

Version définitive du manuscrit publié dans / Final version of the manuscript published in : Lipids, 2008, Online First, DOI: 10.1007/s11745-008-3217-y

121 level, but not the GLP-1 concentration in rats (13), whereas CCK and PYY remained 122 unaffected (8). The anorectic effects of OEA do not imply the modulation of the secretion of 123 satiety signals $(8,13)$.

Satietogenic properties of OEA can also be partially explained by its action on the humans for therapeutic metabolic health. not only due to the decrease of food intake but also to a direct effect on lipid metabolism (4). Ip administration of $5 \mathrm{mg} / \mathrm{kg}$ of OEA in rats increased the expression of FAT/CD36 (fatty acid translocase) in adipose tissues (4). Following this observation, OEA effect was tested on cell cultures of enterocytes and adipocytes. In adipocytes, OEA induced an increase of the FAT/CD36 expression and of the fatty acid release suggesting an increased lipolysis (7), it is also an agonist of the capsaicin receptor TRPV1 that is expressed in preadipocytes. Once activated, this receptor inhibits differenciation of preadipocytes and adipogenesis (16). In enterocytes, an increase of FAT/CD36 expression and of fatty acid uptake was demonstrated after OEA treatment (7). These observations suggest that the increased fatty acid uptake in enterocytes is due to the decreased food intake and body weight gain. OEA would enhance 


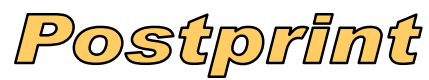

Version définitive du manuscrit publié dans / Final version of the manuscript published in : Lipids, 2008, Online First, DOI: 10.1007/s11745-008-3217-y

147 the utilization of nutrient in the small intestine. These findings support the fact that OEA 148 would play an important role in lipid metabolism by increasing the lipolysis in adipocytes 149 and, simultaneously increasing fatty acid uptake in intestine, partially implicating the 150 modulation of FAT/CD36 expression (7). These results on lipolysis were previously 151 demonstrated in-vivo, suggesting a role of PPAR- $\alpha$ in fatty acid $\beta$-oxidation in muscle through 152 a study performed on PPAR- $\alpha$ null mice (17), but also in obese rats, as OEA treatment can 153 reduced the accumulation of lipid droplets in liver and significantly decrease plasma 154 cholesterol and triglyceride levels (10).

These results suggest that OEA has lipolytic properties through the inhibition of 156 adipogenesis in adipose tissue (16) and the activation of lipid $\beta$-oxidation in muscle (17). Nevertheless, OEA concentration was not decreased during preadipocytes differenciation after the negative control of nor leptin neither PPAR- $\gamma$, contrary to the level of its antiinflammatory analogue palmitoylethanolamide (PEA) (16). These last findings do not favour the local action of OEA on preadipocytes differenciation through the activation of TRPV1 (18). Consequently, the major action of OEA on lipid metabolism would be essentially an increased lipid $\beta$-oxidation in muscle and a better fat utilization through a higher lipolysis in mature adipocytes. These results would have to be confirmed in humans through clinical 164 trials.

\subsection{Oleoylethanolamide (OEA) acts peripherally}

It has been demonstrated that some of the OEA observed peripheral anorexic effects

(4) are mediated by the activation of peroxisome proliferator-activated receptor alpha (PPAR-

$\alpha)$ (19) with a relatively high affinity $(\mathrm{Kd}=37.4 \mathrm{nM})$ compared to other potential endogenous ligands of PPAR- $\alpha$ present in partially digested food such as free fatty acids (20). A study has been performed, in wild-type and PPAR- $\alpha$ knock-out mice, to understand how OEA, which is a potent endogenous PPAR- $\alpha$ agonist, can regulate food intake and body weight gain (10). 


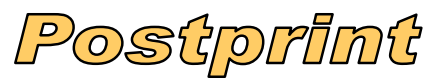

Version définitive du manuscrit publié dans / Final version of the manuscript published in : Lipids, 2008, Online First, DOI: 10.1007/s11745-008-3217-y

173 This study showed that OEA reduces food intake, inhibits body-weight gain and lowers 174 plasma cholesterol levels in wild-type mice, whereas it does not have such effects in PPAR- $\alpha$ mutant mice (10). This implication of PPAR- $\alpha$ in OEA mechanism of action has also been confirmed with some in-vitro gene reporter assays on cell cultures (21).

In addition to its interaction with PPAR- $\alpha$, OEA has been shown to be an agonist of TRPV1. At submicromolar concentrations, OEA activates native TRPV1 in rodents on perivascular sensory nerves and elicits whole cell currents and fluorometric calcium response in human cell lines expressing TRPV1 (22). TRPV1 activation leads to the excitation of peripheral vagal sensory nerves involved in the nervous control of food intake (23). TRPV1 is expressed in both nociceptive neurons, where it is involved in the detection of noxious chemicals and thermal stimuli, and in visceral sensory neurons and brain, where it could have a role on food intake control. OEA was shown to indirectly regulate the activity of TRPV1 and the excitation of sensory nerves expressing TRPV1. Indeed, if TRPV1 is phosphorylated by the protein kinase $\mathrm{C}$, it becomes more sensitive to OEA activation (23). To confirm TRPV1 involvement in OEA effects on food intake, normal mice and TRPV1-null mice were injected with OEA $(12.5 \mathrm{mg} / \mathrm{kg}$ bw). Short-term feeding was significantly reduced in control group but not in TRPV1-null group, showing the role of this receptor in feeding regulation $(22,24)$. Another study was performed in-vivo and in-vitro to establish the relationship between the rat TRPV1 receptor and OEA, employing measurement of ${ }^{45} \mathrm{Ca}^{2+}$ uptake in TRPV1 receptor-transfected cells. OEA showed agonist properties on TRPV1 receptor by stopping ${ }^{45} \mathrm{Ca}^{2+}$ uptake in cells expressing TRPV1 (25). The mechanism of action of OEA on TRPV1 is linked to a $\mathrm{Ca}^{2+}$ concentration modulation inside the cell, inducing an effect on vagal sensory nerves, and, consequently, on food intake regulation. activates GPR119 with an $\mathrm{EC}_{50}$ superior to $\left.30 \mu \mathrm{M}\right)$, has been recently identified in intestinal and pancreatic cells $(26,27)$. This receptor is mainly expressed in the gastrointestinal tract 


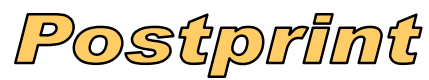

Version définitive du manuscrit publié dans / Final version of the manuscript published in : Lipids, 2008, Online First, DOI: 10.1007/s11745-008-3217-y

and in the pancreas. A specific agonist of GPR119, named PSN632408, has been identified.

The satietogenic efficiency of PSN632408 was investigated in-vivo through intraperitoneal administration $(100 \mathrm{mg} / \mathrm{kg} \mathrm{bw})$. It induced a $30 \%$ decrease of food intake, strongly associated to GPR119 activation. As GPR119 is activated by OEA, it could partially participate to OEA satietigenic effects (26). However, although the implication of GPR119 in food intake regulation has been demonstrated, it is still uncertain whether it can be activated in-vivo by OEA (28).

In Figure 1, a tentative mechanism of action of OEA on the control of food intake is proposed. Fatty acids and derivatives such as OEA are PPAR- $\alpha$ ligands $(\mathrm{Kd}=37.4 \mathrm{nM}$ for OEA) $(19,29)$. OEA can activate intestinal PPAR- $\alpha$ inducing the activation of other nuclear receptor such as RXR. Indeed, PPAR- $\alpha$ and RXR can form an heterodimer that can bind to response elements, leading to the activation of target genes transcription $(29,30)$. These expression modulations would be involved in food intake and lipid metabolism regulation. In addition to this intestinal effect, circulating OEA could block TRPV1 receptor on neuronal cells. This mechanism would modify the electrical status of $\mathrm{Ca}^{2+}$ channel inducing small depolarization (24). Thus, the vagal sensory nerves would be excited, influencing directly food intake regulation.

\subsection{Effects of oleoylethanolamide (OEA) on glucose metabolism}

Rats, intraperitoneally treated with OEA, showed a glucose intolerance compared to control without decreasing the insulin level (31). The effects of OEA on the plasma glucose management were tested in-vivo by performing glucose tolerance tests (31). OEA-treated animals had significantly higher plasma glucose after $30 \mathrm{~min}$ of glucose load, but no other significant differences in any other time points have been noticed, indicating an impairing effect on glucose tolerance on short time rather than a diabetogenic effect (31). 


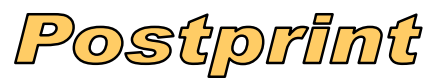

Version définitive du manuscrit publié dans / Final version of the manuscript published in : Lipids, 2008, Online First, DOI: 10.1007/s11745-008-3217-y

Some experiments performed on isolated adipocytes showed that OEA induces a $30 \%$

inhibition of insulin-stimulated glucose uptake and inhibits insulin action (31). These observation can not totally explaine the glucose intolerance observed in rats in-vivo (31), because, on one hand, the glucose transport inhibition due to OEA in adipocytes is really low, and, on the other hand, only part of the glucose clearance from the blood happens in adipocytes, the liver and the skeletal muscle strongly contribute to this phenomenon. Moreover, in another study, OEA administration did not induce modification of blood glucose level at any time point (10), and it has been reported that OEA can trigger phosphorylation of the glucose transporter GLUT4, which could counter-balance the observed OEA inhibition of insulin-stimulated glucose transport (31). Indeed, glucose transport activity has been reported to be mediated by phosphorylation and dephosphorylation of transporters such as GLUT4.

OEA effects on glucose metabolism seem to depend on the tissue, further studies would have to be performed including a glucose tolerance test on hepatic cells.

\section{METABOLISM OF OLEOYLETHANOLAMIDE (OEA) IN ANIMALS}

In mammalian tissue, the synthesis/degradation of OEA occurs mainly in specific cells such as enterocytes (brush border) (32-40), nevertheless, OEA biosynthesis has also been observed in adipose tissue and in insulinoma $\beta$-cells (41). OEA biosynthesis involves two steps, which are catalyzed by two different enzymes named $\mathrm{N}$-acyltransferase (NAT) and $\mathrm{N}$ acyl-phosphatidylethanolamine phospholipase D (NAPE-PLD) (Figure 2) (42, 43). The first step, catalyzed by NAT, consists to the $N$-acylation of an oleic acid residue from membrane phosphatidylcholine (PC) to a phosphatidylethanolamine (PE). Different pathways have been proposed for the formation of $N$-acyl-phosphatidylethanolamine (NAPE) by inter- or intramolecular N-acylation from PE, PC, lyso-PC or cardiolipin (Figure 3) (43). OEA, together with a phosphatidic acid molecule, is released from the NAPE formed by NAPE-PLD- 


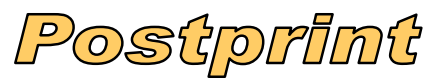

Version définitive du manuscrit publié dans / Final version of the manuscript published in : Lipids, 2008, Online First, DOI: 10.1007/s11745-008-3217-y

250 catalyzed hydrolysis. Alternatively, hydrolysis can be catalyzed by the phosphodiesterase.

OEA can be broken down into oleic acid and ethanolamine by two different hydrolases: Fatty Acid Amide Hydrolase (FAAH) or N-Acylsphingosine Amidohydrolase like protein (ASAH like-protein) (44). FAAH is specific for fatty acid amides and mainly responsible of OEA degradation according to high levels of plasma OEA in FAAH-null mice (15), and ASAH like-protein is a more ubiquitous amidase (Figure 4) (42).

Moreover, the link between OEA and food intake regulation has been shown by Fu et al. (45), indeed feeding stimulates OEA mobilization in the mucosal layer of rat duodenum and jejunum by increasing NAPE-PLD activity and expression and by decreasing amidohydrolase (FAAH) activity and expression. Nutrient availability regulates OEA mobilization in the mucosa of proximal intestine through a concerted regulation of OEA biosynthesis and degradation (45).

Astarita et al. (2) examined whether feeding-induced OEA mobilization can be observed in Burmese pythons (Python molurus), which consumes huge meals after months of fasting. Their way of feeding seems to depend on changes in gastrointestinal hormonal release and gut morphology. A nearly 300-fold increase in OEA levels in the small intestine of fed compared to fasted animals has been observed (2). NAPE species increase simultaneously with OEA in-situ, therefore NAPEs can be considered as potential biosynthetic precursors for OEA.

OEA synthesis in the intestinal mucosa has been extensively studied, less is known about the regulation of OEA synthesis in other tissues. In adipocytes, OEA levels do not variate during differenciation contrary to PEA levels (41), whereas, in insulinoma $\beta$-cells, OEA levels are decreased under "high glucose" conditions (41). In "high glucose" conditions, OEA biosynthesis is activated by glucose and insulin (41). In addition, diabete II patients are caracterised by a higher OEA level in their plasma after food consumption (41). All together, 


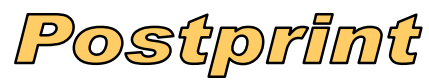

Version définitive du manuscrit publié dans / Final version of the manuscript published in : Lipids, 2008, Online First, DOI: 10.1007/s11745-008-3217-y

275 these results suggest that OEA biosynthesis is downregulated under transient hyperglycemia $276 \quad(41)$.

\section{CONCLUSION AND PERSPECTIVES}

OEA is a very promising molecule, simple derivative of oleic acid, is a transient endogenous signaling lipid formed from PE and PC through the actions of NAT and NAPEPLD. After ingestion, OEA has a short life-time and is cleaved into acid oleic and ethanolamine by the FAAH or the ASAH-like protein in many tissues, including the gastrointestinal tract. The core biological functions of OEA are 1) to control food intake through activation of peripheral PPAR- $\alpha, 2)$ to promote lipid utilization, and 3) to modulate lipid storage in liver and circulating plasma lipids (triglycerides and cholesterol). However, the effects of chronic oral administration of OEA on lipid metabolism and satiety have not been extensively studied to date. The gap between the science and the potential applications in weight management is important and studies evaluating long-term effects and safety are necessary. 


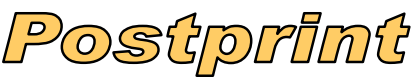

Version définitive du manuscrit publié dans / Final version of the manuscript published in : Lipids, 2008, Online First, DOI: 10.1007/s11745-008-3217-y

\section{REFERENCES}

1. Lambert, D. M., Vandevoorde, S., Jonsson, K. O., and Fowler, C. J. (2002) The palmitoylethanolamide family: a new class of anti-inflammatory agents? Curr Med Chem 9, 663-674

2. Astarita, G., Rourke, B. C., Andersen, J. B., Fu, J., Kim, J. H., Bennett, A. F., Hicks, J. W., and Piomelli, D. (2006) Postprandial increase of oleoylethanolamide mobilization in small intestine of the Burmese python (Python molurus). Am J Physiol Regul Integr Comp Physiol 290, R1407-1412

3. Di Marzo, V., Sepe, N., De Petrocellis, L., Berger, A., Crozier, G., Fride, E., and Mechoulam, R. (1998) Trick or treat from food endocannabinoids? Nature 396, 636637

4. Rodriguez de Fonseca, F., Navarro, M., Gomez, R., Escuredo, L., Nava, F., Fu, J., Murillo-Rodriguez, E., Giuffrida, A., LoVerme, J., Gaetani, S., Kathuria, S., Gall, C., and Piomelli, D. (2001) An anorexic lipid mediator regulated by feeding. Nature 414, 209-212

5. Petersen, G., Sorensen, C., Schmid, P. C., Artmann, A., Tang-Christensen, M., Hansen, S. H., Larsen, P. J., Schmid, H. H., and Hansen, H. S. (2006) Intestinal levels of anandamide and oleoylethanolamide in food-deprived rats are regulated through their precursors. Biochim Biophys Acta 1761, 143-150; discussion 141-142

6. Kirkham, T. C., Williams, C. M., Fezza, F., and Di Marzo, V. (2002) Endocannabinoid levels in rat limbic forebrain and hypothalamus in relation to fasting, feeding and satiation: stimulation of eating by 2-arachidonoyl glycerol. $\mathrm{Br} J$ Pharmacol 136, 550-557

7. Yang, Y., Chen, M., Georgeson, K. E., and Harmon, C. M. (2006) Mechanism of acylethanolamides (OEA) on fatty acid uptake in small intestine after food intake and body weight reduction. Am J Physiol Regul Integr Comp Physiol

8. Proulx, K., Cota, D., Castaneda, T. R., Tschop, M. H., D'Alessio, D. A., Tso, P., Woods, S. C., and Seeley, R. J. (2005) Mechanisms of oleoylethanolamide-induced changes in feeding behavior and motor activity. Am J Physiol Regul Integr Comp Physiol 289, R729-737

9. Gaetani, S., Oveisi, F., and Piomelli, D. (2003) Modulation of meal pattern in the rat by the anorexic lipid mediator oleoylethanolamide. Neuropsychopharmacology $\mathbf{2 8 ,}$ 1311-1316

10. Fu, J., Oveisi, F., Gaetani, S., Lin, E., and Piomelli, D. (2005) Oleoylethanolamide, an endogenous PPAR-alpha agonist, lowers body weight and hyperlipidemia in obese rats. Neuropharmacology 48, 1147-1153

11. Nielsen, M. J., Petersen, G., Astrup, A., and Hansen, H. S. (2004) Food intake is inhibited by oral oleoylethanolamide. J Lipid Res 45, 1027-1029

12. Oveisi, F., Gaetani, S., Eng, K. T., and Piomelli, D. (2004) Oleoylethanolamide inhibits food intake in free-feeding rats after oral administration. Pharmacol Res 49, 461-466

13. Cani, P. D., Montoya, M. L., Neyrinck, A. M., Delzenne, N. M., and Lambert, D. M. (2004) Potential modulation of plasma ghrelin and glucagon-like peptide-1 by anorexigenic cannabinoid compounds, SR141716A (rimonabant) and oleoylethanolamide. Br J Nutr 92, 757-761

14. Aviello, G., Matias, I., Capasso, R., Petrosino, S., Borrelli, F., Orlando, P., Romano, B., Capasso, F., Di Marzo, V., and Izzo, A. A. (2008) Inhibitory effect of the anorexic compound oleoylethanolamide on gastric emptying in control and overweight mice. $J$ Mol Med 86, 413-422 
Version définitive du manuscrit publié dans / Final version of the manuscript published in : Lipids, 2008, Online First, DOI: 10.1007/s11745-008-3217-y

15. Capasso, R., Matias, I., Lutz, B., Borrelli, F., Capasso, F., Marsicano, G., Mascolo, N., Petrosino, S., Monory, K., Valenti, M., Di Marzo, V., and Izzo, A. A. (2005) Fatty acid amide hydrolase controls mouse intestinal motility in vivo. Gastroenterology 129, 941-951

16. Matias, I., Gonthier, M. P., Petrosino, S., Docimo, L., Capasso, R., Hoareau, L., Monteleone, P., Roche, R., Izzo, A. A., and Di Marzo, V. (2007) Role and regulation of acylethanolamides in energy balance: focus on adipocytes and beta-cells. $\mathrm{Br} \mathrm{J}$ Pharmacol 152, 676-690

17. Guzman, M., Lo Verme, J., Fu, J., Oveisi, F., Blazquez, C., and Piomelli, D. (2004) Oleoylethanolamide stimulates lipolysis by activating the nuclear receptor peroxisome proliferator-activated receptor alpha (PPAR-alpha). J Biol Chem 279, 27849-27854

18. Zhang, L. L., Yan Liu, D., Ma, L. Q., Luo, Z. D., Cao, T. B., Zhong, J., Yan, Z. C., Wang, L. J., Zhao, Z. G., Zhu, S. J., Schrader, M., Thilo, F., Zhu, Z. M., and Tepel, M. (2007) Activation of transient receptor potential vanilloid type-1 channel prevents adipogenesis and obesity. Circ Res 100, 1063-1070

19. Fu, J., Gaetani, S., Oveisi, F., Lo Verme, J., Serrano, A., Rodriguez De Fonseca, F., Rosengarth, A., Luecke, H., Di Giacomo, B., Tarzia, G., and Piomelli, D. (2003) Oleylethanolamide regulates feeding and body weight through activation of the nuclear receptor PPAR-alpha. Nature 425, 90-93

20. Lambert, D. M., and Muccioli, G. G. (2007) Endocannabinoids and related Nacylethanolamines in the control of appetite and energy metabolism: emergence of new molecular players. Curr Opin Clin Nutr Metab Care 10, 735-744

21. Astarita, G., Di Giacomo, B., Gaetani, S., Oveisi, F., Compton, T. R., Rivara, S., Tarzia, G., Mor, M., and Piomelli, D. (2006) Pharmacological characterization of hydrolysis-resistant analogs of oleoylethanolamide with potent anorexiant properties. J Pharmacol Exp Ther 318, 563-570

22. Movahed, P., Jonsson, B. A., Birnir, B., Wingstrand, J. A., Jorgensen, T. D., Ermund, A., Sterner, O., Zygmunt, P. M., and Hogestatt, E. D. (2005) Endogenous unsaturated $\mathrm{C} 18 \mathrm{~N}$-acylethanolamines are vanilloid receptor (TRPV1) agonists. J Biol Chem $\mathbf{2 8 0}$, 38496-38504

23. Ahern, G. P. (2003) Activation of TRPV1 by the satiety factor oleoylethanolamide. $J$ Biol Chem 278, 30429-30434

24. Wang, X., Miyares, R. L., and Ahern, G. P. (2005) Oleoylethanolamide excites vagal sensory neurones, induces visceral pain and reduces short-term food intake in mice via capsaicin receptor TRPV1. J Physiol 564, 541-547

25. Almasi, R., Szoke, E., Bolcskei, K., Varga, A., Riedl, Z., Sandor, Z., Szolcsanyi, J., and Petho, G. (2008) Actions of 3-methyl-N-oleoyldopamine, 4-methyl-Noleoyldopamine and $\mathrm{N}$-oleoylethanolamide on the rat TRPV1 receptor in vitro and in vivo. Life Sci

26. Overton, H. A., Babbs, A. J., Doel, S. M., Fyfe, M. C., Gardner, L. S., Griffin, G., Jackson, H. C., Procter, M. J., Rasamison, C. M., Tang-Christensen, M., Widdowson, P. S., Williams, G. M., and Reynet, C. (2006) Deorphanization of a G protein-coupled receptor for oleoylethanolamide and its use in the discovery of small-molecule hypophagic agents. Cell Metab 3, 167-175

27. Sakamoto, Y., Inoue, H., Kawakami, S., Miyawaki, K., Miyamoto, T., Mizuta, K., and Itakura, M. (2006) Expression and distribution of Gpr119 in the pancreatic islets of mice and rats: predominant localization in pancreatic polypeptide-secreting PP-cells. Biochem Biophys Res Commun 351, 474-480

28. Brown, A. J. (2007) Novel cannabinoid receptors. Br J Pharmacol 152, 567-575

29. Desvergne, B., and Wahli, W. (1999) Peroxisome proliferator-activated receptors: nuclear control of metabolism. Endocr Rev 20, 649-688 
Version définitive du manuscrit publié dans / Final version of the manuscript published in : Lipids, 2008, Online First, DOI: 10.1007/s11745-008-3217-y

30. Michalik, L., Auwerx, J., Berger, J. P., Chatterjee, V. K., Glass, C. K., Gonzalez, F. J., Grimaldi, P. A., Kadowaki, T., Lazar, M. A., O'Rahilly, S., Palmer, C. N., Plutzky, J., Reddy, J. K., Spiegelman, B. M., Staels, B., and Wahli, W. (2006) International Union of Pharmacology. LXI. Peroxisome proliferator-activated receptors. Pharmacol Rev 58, 726-741

31. Gonzalez-Yanes, C., Serrano, A., Bermudez-Silva, F. J., Hernandez-Dominguez, M., Paez-Ochoa, M. A., Rodriguez de Fonseca, F., and Sanchez-Margalet, V. (2005) Oleylethanolamide impairs glucose tolerance and inhibits insulin-stimulated glucose uptake in rat adipocytes through p38 and JNK MAPK pathways. Am J Physiol Endocrinol Metab 289, E923-929

32. Ueda, N., Tsuboi, K., and Lambert, D. M. (2005) A second N-acylethanolamine hydrolase in mammalian tissues. Neuropharmacology 48, 1079-1085

33. Hogestatt, E. D., Jonsson, B. A., Ermund, A., Andersson, D. A., Bjork, H., Alexander, J. P., Cravatt, B. F., Basbaum, A. I., and Zygmunt, P. M. (2005) Conversion of acetaminophen to the bioactive $\mathrm{N}$-acylphenolamine AM404 via fatty acid amide hydrolase-dependent arachidonic acid conjugation in the nervous system. J Biol Chem 280, 31405-31412

34. Di Marzo, V. (1999) Biosynthesis and inactivation of endocannabinoids: relevance to their proposed role as neuromodulators. Life Sci 65, 645-655

35. Di Marzo, V., Fontana, A., Cadas, H., Schinelli, S., Cimino, G., Schwartz, J. C., and Piomelli, D. (1994) Formation and inactivation of endogenous cannabinoid anandamide in central neurons. Nature 372, 686-691

36. Cadas, H., Gaillet, S., Beltramo, M., Venance, L., and Piomelli, D. (1996) Biosynthesis of an endogenous cannabinoid precursor in neurons and its control by calcium and cAMP. $J$ Neurosci 16, 3934-3942

37. Cadas, H., di Tomaso, E., and Piomelli, D. (1997) Occurrence and biosynthesis of endogenous cannabinoid precursor, $\mathrm{N}$-arachidonoyl phosphatidylethanolamine, in rat brain. J Neurosci 17, 1226-1242

38. Kuwae, T., Shiota, Y., Schmid, P. C., Krebsbach, R., and Schmid, H. H. (1999) Biosynthesis and turnover of anandamide and other $\mathrm{N}$-acylethanolamines in peritoneal macrophages. FEBS Lett 459, 123-127

39. Khan, S. H., Kaphalia, B. S., and Ansari, G. A. (2005) In vitro conjugation of ethanolamine with fatty acids by rat liver subcellular fractions. $J$ Toxicol Environ Health A 68, 667-676

40. Bisogno, T., Delton-Vandenbroucke, I., Milone, A., Lagarde, M., and Di Marzo, V. (1999) Biosynthesis and inactivation of $\mathrm{N}$-arachidonoylethanolamine (anandamide) and N-docosahexaenoylethanolamine in bovine retina. Arch Biochem Biophys 370, 300-307

41. Matias, I., Petrosino, S., Racioppi, A., Capasso, R., Izzo, A. A., and Di Marzo, V. (2008) Dysregulation of peripheral endocannabinoid levels in hyperglycemia and obesity: Effect of high fat diets. Mol Cell Endocrinol

42. LoVerme, J., Guzman, M., Gaetani, S., and Piomelli, D. (2006) Cold exposure stimulates synthesis of the bioactive lipid oleoylethanolamide in rat adipose tissue. $J$ Biol Chem 281, 22815-22818

43. Schmid, H. H. (2000) Pathways and mechanisms of N-acylethanolamine biosynthesis: can anandamide be generated selectively? Chem Phys Lipids 108, 71-87

44. Sun, Y. X., Tsuboi, K., Zhao, L. Y., Okamoto, Y., Lambert, D. M., and Ueda, N. (2005) Involvement of $\mathrm{N}$-acylethanolamine-hydrolyzing acid amidase in the degradation of anandamide and other $\mathrm{N}$-acylethanolamines in macrophages. Biochim Biophys Acta 1736, 211-220 


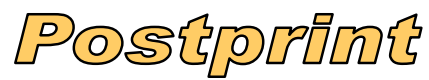

Version définitive du manuscrit publié dans / Final version of the manuscript published in : Lipids, 2008, Online First, DOI: 10.1007/s11745-008-3217-y

45. Fu, J., Astarita, G., Gaetani, S., Kim, J., Cravatt, B. F., Mackie, K., and Piomelli, D. (2007) Food intake regulates oleoylethanolamide formation and degradation in the proximal small intestine. J Biol Chem 282, 1518-1528 


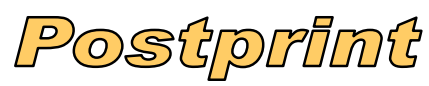

Version définitive du manuscrit publié dans / Final version of the manuscript published in : Lipids, 2008, Online First, DOI: 10.1007/s11745-008-3217-y

443 Legend of Figures.

Figure 1. Mechanism of action of oleoylethanolamide (OEA). PPAR- $\alpha$ and TRPV1 stand

respectively for Peroxisome Proliferator Activated Receptor $\alpha$ and Transient Receptor 446 Potential Vanilloid 1.

447 Figure 2. Metabolism of oleoylethanolamide [OEA, adapted from Lo Verme et al. (42) and 448 Schmid (43)].

449 Figure 3. Inter- and intra-molecular N-acylation of PE from PC [adapted from Schmid (43)].

450 Figure 4. Catabolism of oleoylethanolamide (OEA), adapted from Lo Verme et al. (42). 


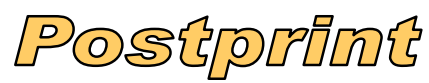

Version définitive du manuscrit publié dans / Final version of the manuscript published in : Lipids, 2008, Online First, DOI: 10.1007/s11745-008-3217-y

Fig 1.

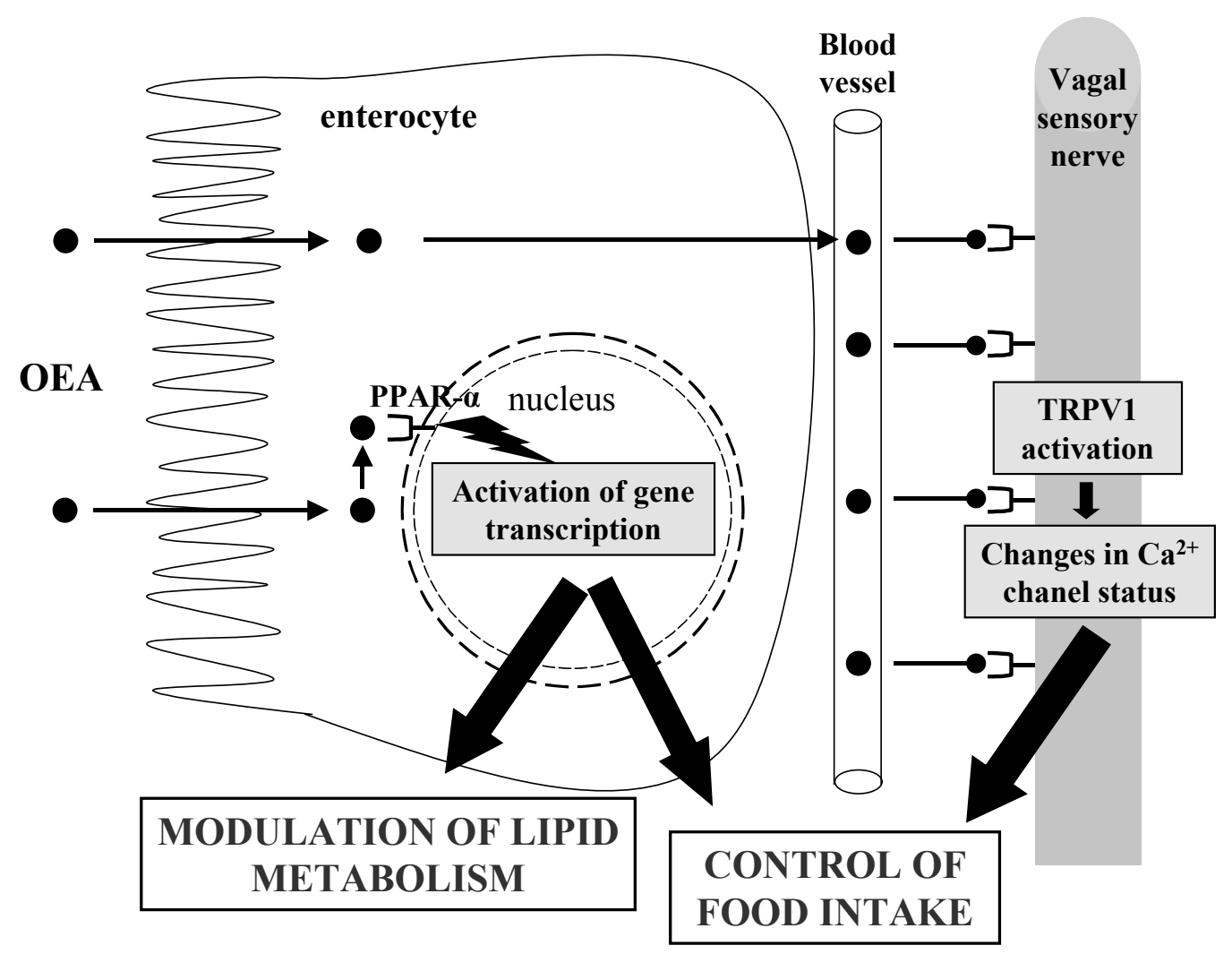




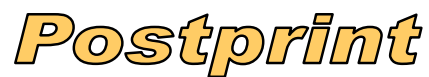

Version définitive du manuscrit publié dans / Final version of the manuscript published in : Lipids, 2008, Online First, DOI: 10.1007/s11745-008-3217-y

Fig 2.

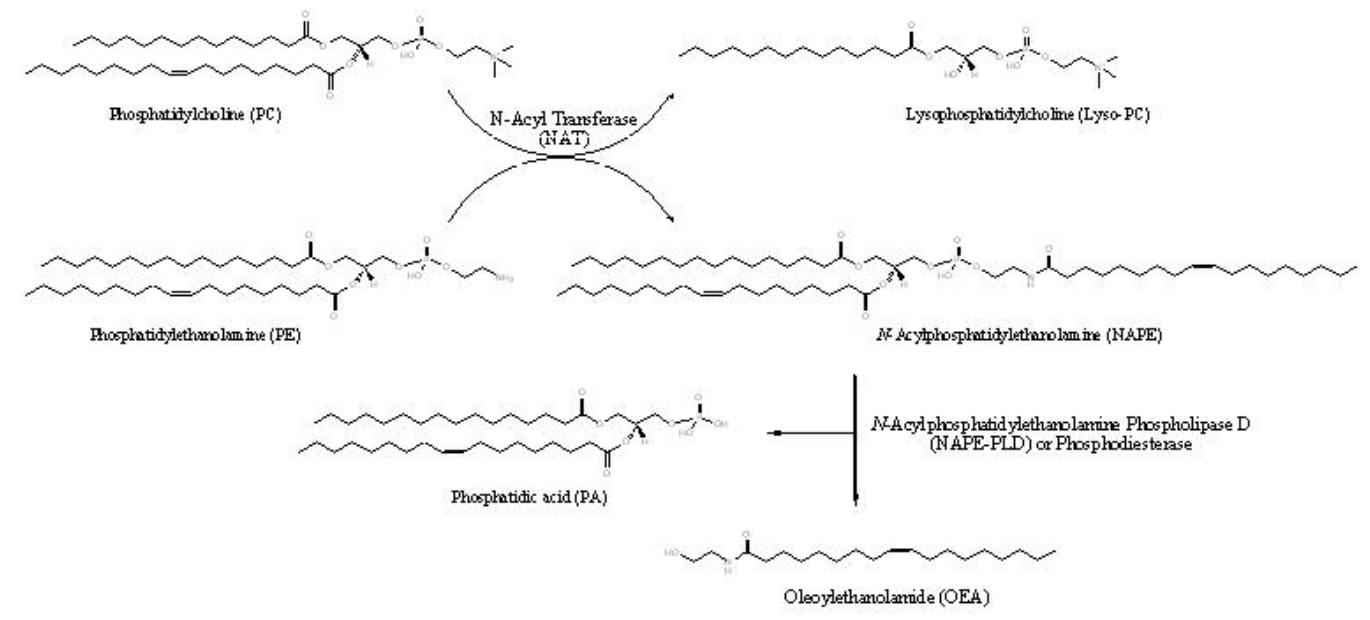




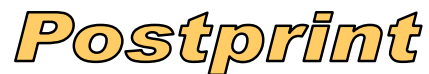

Version définitive du manuscrit publié dans / Final version of the manuscript published in : Lipids, 2008, Online First, DOI: 10.1007/s11745-008-3217-y

Fig 3.

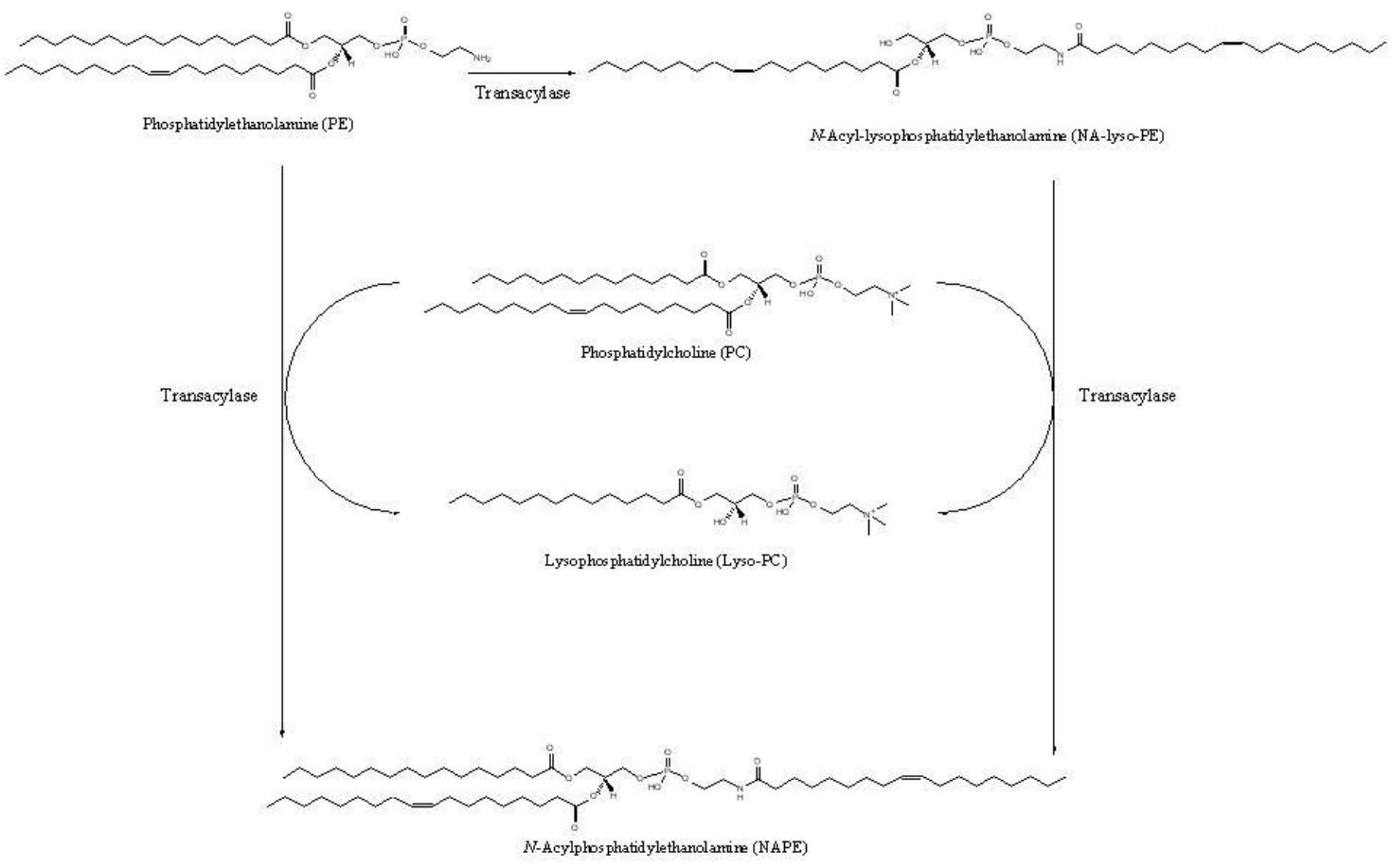




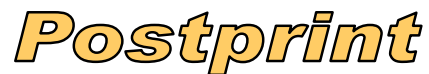

Version définitive du manuscrit publié dans / Final version of the manuscript published in : Lipids, 2008, Online First, DOI: 10.1007/s11745-008-3217-y

Fig 4.

Fatty Acid Amide Hydrolase (FAAH)
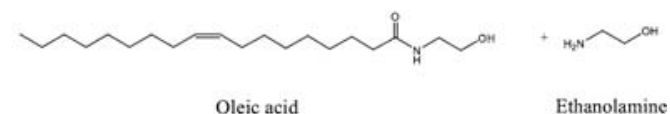